UDK 378.016:81'25

DOI https://doi.org/10.31470/2415-3729-2021-13-246-261

\title{
Methodological Fundamentals of the System of Translation Specialists' Training in Higher Education Institutions on the Basis of Integration
}

\section{Iryna Savka}

Doctor of Philosophy in Pedagogy (Ph.D), Associate Professor of Foreign Languages for the Humanities

Ivan Franko National University of Lviv, $\triangle 1$, Universytetska St., Lviv, Ukraine, 79000

E-mail: savka68@meta.ua

ORCID: https://orcid.org/0000-0002-3213-0921

Date of receipt of the article: April 18, 2021 Article accepted for publication: June 02, 2021

\section{Методологічні засади системи підготовки майбутніх перекладачів у закладах вищої освіти на засадах інтеграції}

\section{Ірина Володимирівна Савка}

кандидат педагогічних наук, доцент кафедри іноземних мов для гуманітарних факультетів Львівського національного університету імені Івана Франка $\triangle$ вул. Університетська, 1, Львів, Україна, 79000

Дата надходження статті: 18 квітня 2021 p. Стаття прийнята до друку: 02 червня 2021 р.

\section{Abstract}

The article highlights the approaches to the effective training of a professional translator. The purpose of the article is to describe the features of translation specialists' training at higher educational institutions, the methodological principles and approaches of the system of translation specialists' training at higher educational institutions. Methods. The study involves the use of integration analysis methods during learning students, a set of interrelated methods: theoretical analysis, comparison and generalization of scientific sources on the research problem; systematization, classification, experts' assessments, etc. The results. It 
is determined that the following approaches necessary for professional training of a professional translator in higher school are: methodological approach; systematic approach; competency approach; axiological approach; acmeological approach; activity approach; synergetic approach and linguopsychological approach. The proposed scientific approaches to improving the professional future translators' training outline a wide range of different aspects of students' readiness for professional activity in the field of translation. It is proved that in the future translation specialists' training it is necessary to choose the principles of training taking into account that the methodological principles should correspond to the goals of training and that the methodological principles should be based on the concepts of training methods. Conclusions. It is found that the main principles for the training of translation specialists should be considered general didactic principles (principles of consciousness, clarity, strength, scientificity, emotionality, cognition, systematicity and consistency) and specific principles (intercultural communication, roleplaying, clarity, interdisciplinary connections and language competence). The benefit of the study is that the specific principles that determine the requirements for the organization of future translators' training process are substantiated. The implementation of these principles can ensure the successful achievement of learning objectives, contributing to the intensification, productivity, efficiency and rationalization of forming the future translation specialists' receptive language competencies.

Key words: professional translator's training, scientific approaches, general didactic principles, specific principles.

\section{References}

1. Babanskiy, Yu. K. (1997). Optimizatsiya protsessa obucheniya [Optimization of the learning process]. Moskva: Pedagogika [in Russian].

2. Балл, Г. О. et al. (2001). Психологія праці та професійної підготовки особистості [Psychology of labour and vocational training]: Х Хмельницький: «Універ» [in Ukrainian].

3. GalperIn, P. Ya. (1966). Psihologiya myishleniya $i$ uchenie o poetapnom formirovanii umstvennyih deystviy [Psychology of thinking and the doctrine of the gradual formation of mental actions]. 
In E.V. Schorohovoy (Ed.) Issledovaniya myishleniya $v$ sovetskoy psihologii [Research on thinking in Soviet psychology]. (pp. 259-276). Moskva: «Nauka» [in Russian].

4. Kolodii, I. A. (2009). Aspekty formuvannia intehralnoi profesiinoi kompetentnosti u maibutnikh perekladachiv aviatsiinoi haluzi [Aspects of the forming the future aviation translators integrated professional competence]. Visnyk pisliadyplomnoi osvity - Bulletin of postgraduate education, 11(1), 112?118. Retrieved from http://nbuv. gov.ua/UJRN/Vpo_2009_11\%281\%29_16 [in Ukrainian].

5. Panzyha, O. M. (2014). Realizatsiia dydaktychnykh i metodychnykh pryntsypiv $u$ protsesi formuvannia retseptyvnykh movnykh kompetentnostei druhoi inozemnoi movy u maibutnikh uchyteliv [Realization of didactic and methodological principles in the forming future teachers receptive linguistic competences of second foreign language]. Visnyk Kyivskoho natsionalnoho linhvistychnoho universytetu. Ser. : Pedahohika ta psykholohiia - Visnyk of Kyiv National Linguistic University. Ser. : Pedagogy and psychology, 23, 129-138 [in Ukrainian].

6. Romanyshyna, L. M., Ostrovska, N. D. \& Marchyshyn, S. M. (2010). Teoretychni osnovy neperervnoi profesiinoi pidhotovky fakhivtsiv $\mathrm{u}$ vyshchykh navchalnykh zakladakh [Theoretical bases of continuous professional training of specialists in higher educational institutions] Visnyk Natsionalnoi akademii Derzhavnoi prykordonnoi sluzhby Ukrainy - Bulletin of the National Academy of the State Border Guard Service of Ukraine (Vol. 5). Retrieved from http://nbuv.gov.ua/UJRN/ Vnadps_2010_5_14 [in Ukrainian].

7. Tsvilling, M. Yaa. (1998). Professionalnyie trebovaniya k lichnosti perevodchika i obuchenie perevodu [Professional requirements for the personality of the translator and translation training]. Informatsionnokommunikativnyie aspektyi perevoda - Information and communication aspects of translation]. (Part II, pp. 141-150). Nizhniy Novgorod : NGLU [in Russian].

8. Tsyhan, L. V. (2013). Pryntsypy navchannia maibutnikh filolohiv usnoho perekladu [Principles of teaching interpretation to prospective intepreters]. Visnyk Chernihivskoho natsionalnoho pedahohichnoho pedahohichnoho universytetu - Bulletin of the Chernihiv National Pedagogical University, 111, 373-375 [in Ukrainian]. 
9. Davison, D., Kenneth, M. \& Dixie, M. (1995). What Does Integration of Science and Mathematics Really Mean?. School Science and Mathematics. Vol. 95. P. 226-230.

\section{Вступ}

Сучасні глобальні зміни суттєво впливають на формування змісту професійної підготовки.

Вимоги до майбутніх фахівців з перекладу передбачають їх високу продуктивність, гнучкість, здатність адаптуватися до швидких змін умов функціонування галузі, формування інноваційного змісту освіти тощо.

Підготовка фахівців з перекладу полягає у поєднанні гуманітарної підготовки та професійної підготовки у певній галузі знань чи практичної діяльності.

Для підготовки майбутніх перекладачів, для розвитку їх ділових та особистісних якостей, дослідники вважають за доцільне використовувати різні загальнонаукові підходи.

У психолого-педагогічній літературі досліджувалися питання: інтеграції методів навчання для формування іншомовної компетенції (Девідсон Д., Колодій І. А., Козловський Ю. М.), використання методичних принципів у формуванні мовної компетенції (Панзига О. М., Циган Л. В.), питання методики викладання перекладу (Бондаренко О. М.), методи та формування перекладацької компетенції студентів-перекладачів (Коротяєва І. Б.) тощо.

Метою статті є дослідити особливості підготовки фахівців 3 перекладу у 3ВО; описати методологічні принципи та підходи системи підготовки майбутніх перекладачів у ЗВО.

\section{Матеріал і методи дослідження}

Дане дослідження передбачає використання методів інтеграційного аналізу під час навчання студентів. Застосовано комплекс взаємопов'язаних методів: теоретичний аналіз, порівняння та узагальнення наукових джерел із досліджуваної проблеми; систематизація, класифікація експертні оцінки тощо.

\section{Результати та їх обговорення}

В науковій літературі «Підхід» розглядається як світоглядна категорія, що відображає загальні погляди студентів як представників громадського світогляду; загальна i комплексна організація та 
самоорганізація освітнього процесу, що включає усі його компоненти і суб'єктів педагогічної взаємодії; базова ціннісна орієнтація педагога, що визначає його позицію до взаємодії у навчальному процесі; сукупність (система) принципів, що визначає загальну мету та стратегію відповідної діяльності, незалежно від того, чи є вона теоретичною чи практичною.

Тому, ми вважаємо за доцільне використовувати наступні підходи для ефективної підготовки фахового перекладача: методологічний підхід; системний підхід; компетентнісний підхід; аксіологічний підхід; акмеологічний підхід; діяльнісний підхід; синергетичний підхід; лінгвопсихологічний підхід тощо.

Для ефективної професійної підготовки майбутніх перекладачів необхідна реалізація системного підходу, який передбачає вивчення організації праці викладачів та студентів, їх аналіз з позицій наукової організації праці; дослідження взаємозв'язків між компонентами системи на основі комплексу сучасних наукових методів; удосконалення на цій основі організації діяльності студентів і педагогічної праці викладачів; проектування принципово нової організації навчання майбутніх фахівців.

Системний підхід в системі структурно-функціонального дуального змісту професійної підготовки фахівця повинен враховувати взаємовідносини та зв'язки різних елементів цілого, знаходити в системі відносини між елементами, провідні тенденції та основні закономірності у структурі.

Варто згадати застосування компетентнісного підходу для підготовки майбутніх перекладачів.

Компетентність майбутніх перекладачів це результативнодіяльнісна характеристика особистості, ії спроможність кваліфіковано провадити діяльність через набір знань, умінь, навичок і ставлень, що дають змогу фахівцю належно виконувати професійні функції, необхідні у професійній перекладацькій діяльності.

Компетенцію не можливо відділити від діяльності, в якій i задля якої індивід свідомо використовує свої знання та вміння. Компетенція оцінюється тільки через діяльність особистості. Компетенція формується особистісними властивостями, які властиві особі у будь-якій ситуації, а з виникненням професійної виробничої ситуації реалізуються адекватно до іiі вимог, а саме евристичність 
(вміння передбачати, прогнозувати, знаходити вирішення проблеми), стратегічність (здатність поєднувати вміння, навички та знання відповідно до поставленої мети), винахідливість (вміння поєднувати нові елементи) тощо.

Одназосновних видів компетентносей, методична компетентність, означає володіння системою методів навчання і виховання, що сприяють творчому розвитку і саморозвитку. Соціально-психологічна компетентність характеризує поінформованість у сфері спілкування, міжособистісних відносин і тому тісно пов'язана із диференційнопсихологічною компетентністю.

Тому при підготовці майбутніх перекладачів реалізація компетентнісного підходу дотримання низки дидактичних умов. полягає в чіткому усвідомленні учасниками навчального процесу дидактичної своєрідності. Компетентнісний підхід підготовки майбутніх перекладачів визначає готовність і здатність вирішувати різні професійні та життєві проблеми. Компентентісний підхід відображає результат професійної підготовки майбутніх перекладачів як цілісну систему ознак готовності студентів до здійснення професійної діяльності.

Ще одним важливим підходом у підготовці майбутніх перекладачів $€$ аксіологічний підхід, оскільки він дозволяє закріпити ціннісні становлення майбутніх перекладачів до професійної діяльності; розглядати майбутніх фахівців, як креативну особистість, яка здійснює діяльність 3 високою та стабільною продуктивністю, яка відображає високий рівень особистісноділових та професійно важливих якостей

Наступним підходом, який вартий уваги при підготовці фахових перекладачів $є$ акмеологічний. Акмеологічний підхід дозволив обгрунтувати вибір ефективних параметрів та критеріїв якості, котрі дозволять ефективно керувати організаційною та змістовною частиною навчального процесу, який забезпечує самостійний ріст та рух студента до вершин професіоналізму.

При застосуванні діяльнісного підходу можливо з'ясувати особливості організації процесу професійної підготовки 3 урахуванням формування професійної компетентності майбутніх перекладачів. Антропологічний підхід дозволив здійснити систему знань про людину - суб'єкта та об'єкта освіти, що базуються на синтезі теоретико-педагогічного, філолофсько-антропологічного 
й людинознавчого знання. До теперішнього часу вже сформувалося поняття про антропологічні підстави теорії й практики освіти. Для майбутнього перекладача важливою є та обставина, що в переліку елементів педагогічної антропології поряд з філософією, педагогікою, психологією, соціологією, включені дисципліни: культурологія, валеологія, що дозволив вдосконалити професійну підготовку майбутніх перекладачів.

Діяльнісний підхід є необхідним у дослідженні позааудиторної навчально-виховної діяльності, оскільки вона носить предметний характер та постає перед студентом у формі нормативно погодженого способу діяльності, який у результаті стає індивідуальним способом власної діяльності (Бабанський, 1997:29).

Варто взяти до уваги і синергетичний підхід як засіб аналізу позааудиторної діяльності визначає інтеграцію людини та світу як двох системних утворень. Завдання цієї діяльності визначаються спрямованістю педагога до мобілізації вихованця до міркувань про суть та походження речей, до пошуку цілісного життєвого змісту, осягнення мистецтва мислетворчості.

У професійній підготовці перекладачів не можливо оминути лінгвопсихологічний підхід, оскільки у перекладі він спрямований на вивченні безпосередньо процесу перекладу, на дослідження ролі людини у перекладі, на ролі психології у прийнятті перекладачем тих чи інших рішень у певних професійних ситуаціях. Психологія перекладу охоплює питання двомовності (білінгвізму) та питання автоматизмів (при здійсненні синхронного перекладу), питання співдіяння мислення на різних мовах, а також внутрішньої мови і перекладу тощо.

Психологія перекладу пов'язана 3 відношенням мови до мислення, 3 мовними образами. Науковець відслідковує психологічні аспекти перекладу безпосередньо під час вивчення іноземної мови. Він вважає, що під час вивчення певних аспектів перекладу, варто враховувати питання процесу засвоєння мови - тобто психологічний підхід (Гальперін, 1966).

Отже, на основі узагальнення можна зробити висновок, що наукові підходи до вдосконалення професійної підготовки майбутніх перекладачів окреслюють широку палітру різних аспектів готовності студентів до професійної діяльності у галузі перекладу. 
Принципи навчання (дидактичні принципи) - це фундаментальні ідеї, що проходять через всю систему науково-дидактичних знань і підпорядковують їх навчальній дисципліні (Цвиллинг, 1998:142).

Вчені розрізняють багато загально дидактичних принципів навчання, серед яких ми використали: науковості, свідомості, наочності, грунтовності, активності, самостійності та доступності.

Для з'ясування сутності принципу професійної підготовки ми спираємося на визначення принципу як вихідної керівної ідеї. У логічному сенсі принцип - центральне поняття, підстава системи, що припускає узагальнення і розповсюдження цього положення всі явища у галузі, з якої цей принцип виокремлений.

Зазвичай існують дві групи принципів навчання — класичні i сучасні.

Щодо класичних принципів дидактики то можна віднести: принципи науковості, свідомості і самостійності, систематичності, послідовності, наступності, наочності, доступності, міцності, зв’язку теорії та практики. Всі вони зберігають своє значення і для сучасної дидактики.

Для ефективною організації підготовки фахівців 3 перекладу необхідно врахувати такі принципи навчання, що визначають вимоги як до системи навчання в цілому, так і до її окремих компонентів - цілей, змісту, форм і методів навчання. Отже, нам необхідно розглянути специфічні принципи, які $є$ актуальними у процесі навчання певного аспекту навчальної дисципліни, іноземної мови та перекладу.

У підготовці майбутніх фахівців з перекладу потрібно обрати принципи навчання з урахованням того, що методичні принципи повинні відповідати цілям навчання та те, що методичні принципи повинні виходити із закономірностей методики підготовки фахівців, а також із законів суміжних наук, що забезпечують інтеграцію закономірностей методики і суміжних 3 нею наук для оптимізації підготовки фахівців.

Отже, основними для підготовки фахівців з перекладу потрібно вважати загальнодидактичні (принципи свідомості, наочності, міцності, науковості, емоційності, когнітивності, систематичності i послідовності) і специфічні принципи (міжкультурної комунікативності, рольових вправ, наочності,між предметних зв'язків та мовленнєвої компетентності) (Романишина, 2010:171). 
Своєрідність цього принципу у підготовці перекладачів полягає в урахуванні методики навчання іноземної мови, соціальної психології - про особливості комунікації за допомогою мови, психолінгвістики - про вплив мови на розвиток особистості (Панзига, 2014:130].

Принцип науковості означає у навчанні іноземних мов, що навчальний процес повинен брати до уваги здобутки сучасної науки про особливості комунікації за допомогою мови, закономірності розпізнавання та походження мовлення та мовних контактів.

Принцип науковості у підготовці фахівців з перекладу передбачає науково обгрунтований відбір мовного матеріалу для активного і пасивного володіння, у дотриманні нормативності використання мовних засобів у всіх видах мовленнєвої діяльності,

Ми вибрали такі специфічні принципи підготовки фахівців 3 перекладу:

- принцип підготовки майбутніх перекладачів в міжкультурному контексті;

- принцип урахування психологічних особливостей функціонування розумових особливостей перекладача;

- принцип взаємопов' язаного формування мовних компетентностей і методичної компетентності.

Принцип систематичності й послідовності полягає у послідовному використанні змісту знань, видів діяльності у навчальних програмах, підручниках, навчальних посібниках тощо, дотримання такого самого порядку засвоєння знань, формування вмінь та навичок. Під час підготовки перекладачів передбачає вивчення всіх граматичних явищ у чіткій послідовності та системності iз систематичним використанням зіставлення, що дає змогу створювати у студентів абстрактне уявлення про зміст граматичного явища і формувати вміння самостійного наукового пошуку (Балл, 2001:55). Навчання лексичного матеріалу теж відбувається у чіткій послідовності.

Значну роль відіграє наступність поетапного навчання : отримані знання, сформовані навички та вміння вивчення іноземної мови у часовому значенні були раніше, а наступним етапом стало опанування іноземної мови.

У підготовці перекладачів принцип системності передбачає усвідомлення мови як цілісної системи, що складається з набору мов- 
них і мовленнєвих елементів та правил їх використання, засвоєння необхідних термінів для точного розуміння та опису мовних явищ.

Відповідно до принципу системності та послідовності, навчання відбувається за системою, яка забезпечує збереження наступності змістової та процесуальної сторін навчання, закріплення знань, умінь, навичок, особистісних якостей індивіда, їх послідовний розвиток i удосконалення (Колодій, 2009:69).

Варто згадати і принцип комунікативної спрямованості підготовки перекладачів який передбачає:

- демонстрацію нового граматичного явища у контексті (в діалозі, монолозі, тексті для читання та аудіювання, листі тощо), адже саме там аутентичний граматичний матеріал у реальному спілкуванні;

- надання комунікативної спрямованості навіть тренувальним вправам, коли учні імітують, трансформують, доповнюють, але при цьому реалізують комунікативні наміри (Гальперін, 1966:10).

При вивченні іноземних мов одним iз основних принципів вважається принцип свідомості. Цей принцип полягає у цілеспрямованому підборі навчального, мовного та мовленнєвого матеріалу, який спрямований на розвиток пізнавальних здібностей студентів.

Принцип свідомості здійснюється також усією організацією підготовки фахівців з перекладу, протягом якої відбувається навчання від усвідомлення правил виконання дії до їі автоматизовані виконання, від формування окремих елементів діяльності до їх об'єднання. Цей принцип полягає у тому, що навчання проходитиме успішно, якщо студент буде усвідомлювати те, що вчить, а не повторюватиме механічно новий матеріал.

Отже, принцип свідомості передбачає усвідомлення мовних одиниць і правил їх функціонування та використання; здатність самостійно обирати форми відповідно до змісту висловлювання; усвідомлення ступеню успішності засвоєння мовного матеріалу та здатності використовувати його у різних професійних ситуаціях.

Необхідним у підготовці перекладачів є принцип емоційності навчання. Принцип емоційності навчання походить 3 природи розвитку й діяльності студентів. Емоції - це психічні процеси, які пов’язані iз людськими інстинктами, потребами і мотивами, які 3'являються у вигляді переживань (задоволення, радості, страху тощо) і вплива- 
ють на життєдіяльність людини. Емоції також впливають на перебіг діяльності. Вони можуть використовуватися як внутрішня мотиваційна сила у підготовці перекладачів. У даному випадку потрібно брати до уваги позитивні емоції. Емоції страху, ненависті та інші негативні емоції не відіграють роль мотиваційної сили у навчанні, а радше сповільнюють дії, активність думки тощо. Почуття впевненості у своїх силах студентів, задоволення у досягненні поставленої мети стимулюють успішність навчання, У студентів 3'являється прагнення подолати різні труднощі у навчанні. Під час навчання необхідно підтримувати позитивні емоції, що сприяє усуванню напруження, психологічні стримування, «розкріпачує» студента (Davison, Kenneth \& Dixie, 1995:130).

Одним 3 провідних принципів у підготовці фахівців 3 перекладу $є$ принцип когнітивної спрямованості підготовки. Цей принцип полягає у приділення особливої уваги ментальній діяльності студентів 3 утворення лінгвістичних явищ, а саме - організацію пізнавальних дій студентів, відповідну процесу природного пізнавання.

Відповідно до принципу когнітивної спрямованості у підготовці перекладачів особливий акцент переноситься на врахування пізнавального процесу при оволодінні іноземної мови та особливості ментальної діяльності того, хто навчається. Оптимальною визначається така організація навчального процесу, яка, з одного боку, збігається 3 природним шляхом пізнання, притаманним психіці людини, а 3 іншого боку, сприяє іï когнітивному розвитку.

Підготовка фахівців з перекладу здійснюється на основі методичних принципів серед яких варто виділити такі:

- наочності (принцип наочності у процесі підготовки перекладачів полягає у створенні відповідних умов для чуттєвого сприймання іншомовного середовища).

- принцип комплексності (підготовка перекладачів пов'язана 33 нагромадженням засвоєного мовного та мовленнєвого матеріалу та перекладацьких навичків).

- принцип активності (передбачає мовленнєво-розумову активність студентів в оволодінні іншомовною мовленнєвою діяльністю).

- принцип урахування міжпредметних зв'язків (полягає в узгодженому вивченні теорій законів, понять, спільних для споріднених предметів, загальнонаукових методів пізнання й методологічних 
принципів, формування спільних видів діяльності та систем відношень).

- принцип системного активності і самостійності у навчанні (грунтується на розумінні мотиву як стимулу діяльності, пов'язаного iз задоволенням потреб особистості).

- принцип взаємопов'язаного формування мовних компетентностей і методичної компетентності тощо. (формуванні рецептивних мовних компетентностей 3 іноземної мови у тренувальних вправах на імітацію. В основу специфічних принципів покладено розуміння мови як інструмента спілкування та інструмента пізнання, а також урахування особливостей вивчення іноземної мови).

Щодо специфічних принципів підготовки фахівців з перекладу то варто згадати принцип міжкультурної комунікації, реалізація якого $є$ основним шляхом формування соціокультурної компетенції у майбутнього перекладача. передбачає знайомство і порівняння культур народів виучуваних мов.

Принцип індивідуалізації у підготовці перекладачів здійснюється за допомогою урахування індивідуально-психологічних особливостей студента, які мають значний вплив на успішність опанування іншомовною мовленнєвою діяльністю. Отже, для реалізації даного принципу необхідно визначити індивідуально-психологічні особливості студентів і врахувати їх під час професійної підготовки перекладачів.

Основним методичним принципом, який допомагає в успішному досягненні головної мети підготовки перекладачів у закладах вищої освіти, тобто навчанні студентів здійснювати іншомовне мовленнєве спілкування в межах засвоєного навчального матеріалу є принцип комунікативності.

Принцип контрастивного підходу при підготовці перекладачів полягає у пошуку та виявленні розбіжностей між мовою, яка вивчається та рідною мовою. Принцип використання контрастивного підходу використовує зіставлення та порівняння, в іншому випадку, коли немає схожості.

Кожен принцип виконує по відношенню до іншого певні функції, які є одночасно і його функціями в процесі навчання. Тому висунуті принципи навчання є системно-цілісні в сумарному значенні. 


\section{Висновки}

Таким чином, на основі аналізу загальнодидактичних і загальнометодичних принципів навчання, були обгрунтовані специфічні принципи, що визначають вимоги до організації процесу навчання майбутніх перекладачів. Реалізація цих принципів може забезпечити успішне досягнення цілей навчання.

Отже, ми можемо стверджувати, що реалізація зазначених дидактичних та методичних принципів з урахуванням специфіки підготовки перекладачів сприятиме інтенсифікації, продуктивності, ефективності та раціоналізації формування рецептивних мовних компетентностей у майбутніх фахівців з перекладу.

\section{Література}

1. Бабанський Ю. К. Оптимизация процесса обучения. Москва: Педагогика. 1997. 103 с.

2. Психологія праці та професійної підготовки особистості : навч. посіб. / Г. О. Балл та ін.; Акад. пед. наук України. Ін-т педагогіки і психології проф. освіти. Хмельницький: «Універ», 2001. 329 с.

3. Гальперін П. Я. Психология мышления и учение о поэтапном формировании умственных действий. Исследования мылиления в советской психологии / под ред. Е.В. Щороховой . Москва: «Наука» 1966, С. 259-276.

4. Колодій I. А. Аспекти формування інтегральної професійної компетентності у майбутніх перекладачів авіаційної галузі. Вісник післядипломної освіти. 2009. Вип. 11(1). С. 112-118. URL: http://nbuv.gov.ua/UJRN/Vpo_2009_11\%281\%29_16.

5. Панзига О. М. Реалізація дидактичних і методичних принципів у процесі формування рецептивних мовних компетентностей другої іноземної мови у майбутніх учителів. Вісник Київського національного лінгвістичного університету. Сер. : Педагогіка та психологія. 2014. Вип. 23. С. 129-138.

6. Романишина Л. М., Островська Н. Д., Марчишин С. М. Теоретичні основи неперервної професійної підготовки фахівців у вищих навчальних закладах. Вісник Національної академії Державної прикордонної служби України. 2010. Вип. 5. URL: http://nbuv.gov.ua/UJRN/Vnadps_2010_5_14.

7. Цвиллинг М. Я. Профессиональные требования к личности переводчика и обучение переводу. Информационно-коммуникатив- 
ные аспекты перевода. Часть II. Нижний Новгород : НГЛУ, 1998. C. 141-150.

8. Циган Л. В. Принципи навчання майбутніх філологів усного перекладу. Вісник Чернігівського національного педагогічного педагогічного університету. 2013. Вип. 111. C. 373-375.

9. Davison D., Kenneth M., Dixie, M. What Does Integration of Science and Mathematics Really Mean?. School Science and Mathematics. 1995, Vol. 95. pp. 226-230.

\section{Савка I.B.}

\section{Методологічні засади системи підготовки майбутніх перекладачів у закладах вищої освіти на засадах інтеграції}

\section{Анотація}

У статті висвітлені підходи для ефективної підготовки фахового перекладача. Визначено, що для професійної підготовки фахового перекладача у ЗВО необхідні наступні підходи: методологічний підхід; системний підхід; компетентнісний підхід; аксіологічний підхід; акмеологічний підхід; діяльнісний підхід; синергетичний підхід; лінгвопсихологічний підхід.

Запропоновані наукові підходи до вдосконалення професійної підготовки майбутніх перекладачів окреслюють широку палітру різних аспектів готовності студентів до професійної діяльності у галузі перекладу.

Доведено, що у підготовці майбутніх фахівців 3 перекладу потрібно обрати принципи навчання 3 урахуванням того, що методичні принципи повинні відповідати цілям навчання та те, що методичні принципи повинні виходити із закономірностей методики підготовки фахівців,

3'ясовано, що основними для підготовки фахівців 3 перекладу потрібно вважати загальнодидактичні (принципи свідомості, наочності, міцності, науковості, емоційності, когнітивності, систематичності і послідовності) i специфічні принципи (міжкультурної комунікативності, рольових вправ, наочності, міжпредметних зв’ язків та мовленнєвої компетентності). 
Обгрунтовано специфічні принципи, що визначають вимоги до організації процесу навчання майбутніх перекладачів. Реалізація цих принципів може забезпечити успішне досягнення цілей навчання.

Ключові слова: підготовки фахового перекладача, наукові підходи, загальнодидактичні принципи, специфічні принципи.

\section{Савка И.В.}

\section{Методологические основы системы подготовки будущих пе- реводчиков в учреждениях высшего образования на основе интеграции}

\section{Аннотация}

В статье освещены подходы к эффективной подготовке профессионального переводчика. Определено, что для профессиональной подготовки профессионального переводчика в 3 ВО необходимы следующие подходы: методологический подход; системный подход; компетентностный подход; аксиологический подход; акмеологический подход; деятельностный подход; синергетический подход; лингвопсихологический подход.

Предложенные научные подходы к совершенствованию профессиональной подготовки будущих переводчиков определяют широкую палитру различных аспектов готовности студентов к профессиональной деятельности в области перевода.

Доказано, что в подготовке будущих специалистов по переводу нужно выбрать принципы обучения с учетом того, что методические принципы должны соответствовать целям обучения и то, что методические принципы должны исходить из закономерностей методики подготовки специалистов,

Установлено, что основными для подготовки специалистов по переводу нужно считать общедидактичиские (принципы сознательности, наглядности, прочности, научности, эмоциональности, когнитивности, систематичности и последовательности) и специфические принципы (межкультурной коммуникативности, ролевых упражнений, наглядности, межпредметных связей и речевой компетентности). 
Обоснованно специфические принципы, определяющие требования к организации процесса обучения будущих переводчиков. Реализация этих принципов может обеспечить успешное достижение целей обучения.

Ключевые слова: подготовки профессионального переводчика, научные подходы, общедидактичиские принципы, специфические принципы. 